\title{
Effects of Branched Chain Amino Acids on digestive enzymes secretion from pancreas of dairy cows
}

\author{
Mengya Wang \\ Inner Mongolia Agricultural University \\ Xuan Ma \\ Inner Mongolia Agricultural University \\ Donglin Wu \\ Inner Mongolia Agricultural University \\ Xueliang Zhao \\ Northwest Agriculture and Forestry University \\ Kai Shao \\ Inner Mongolia Agricultural University \\ Ru Li \\ Inner Mongolia Agricultural University \\ Ming Xu ( 13624710492@163.com) \\ Inner Mongolia Agricultural University
}

\section{Research}

Keywords: a-amylase, pancreas, Leucine, Isoleucine, Valine, Cows, in vitro

Posted Date: December 13th, 2019

DOI: https://doi.org/10.21203/rs.2.18628/v1

License: () (i) This work is licensed under a Creative Commons Attribution 4.0 International License. Read Full License 


\section{Abstract}

Background : The limited ability of ruminant to digest starch in the small intestine may be attributed to insufficient digestive enzyme activity secreted by the pancreas. The purpose of this study was to investigate effects of leucine (Leu), isoleucine (lle) and valine (Val) on digestive enzymes secretion from pancreas collected of Holstein dairy cows by tissue incubation in vitro.

Methods: Two experiments were designed in the present study. In experiment 1, Five Holstein dairy cows were slaughtered and pancreatic tissue was removed immediately, rinsed with ice-cold normal saline $(0.9 \% \mathrm{Nacl})$ and cut into small segments (approximately $2 \times 2 \mathrm{~mm}$ ), which were placed in oxygenated Krebs Ringer bicarbonate buffer (KRB) containing no amino acid (control), leu, lle or Val $\left(2.62,5.24\right.$ or $10.48 \mathrm{mg} / \mathrm{mL}$ ). Each treatment was repeated for five times and incubated in a $39^{\circ} \mathrm{C}$ shaker. KRB and pancreatic tissue samples were collected at 60,120 and 180 min after the incubation. In experiment 2, Five Holstein dairy cows were slaughtered and the pancreatic tissue was immediately removed and treated, which were placed in KRB containing no amino acid (control), leu, lle or Val (5.24 mg/mL) for incubation $60 \mathrm{~min}$.

Results : In experiment 1, The activity of pancreatic a-amylase were increased by Leu $(P<0.01)$, lle $(P<0.01)$ or Val $(P=0.06)$. Compared with the control group, Leu $(P<0.05)$ or lle $(P<0.05)$ could linearly increase the activity of trypsin, but Val $(P>0.05)$ had no effect on the trypsin activity. Neither Leu or Val had no influence on the activity of chymotrypsin $(P>0.05)$. However, chymotrypsin activity decreased linearly with the increase of the lle concentration at incubation time $180 \mathrm{~min}(\mathrm{P}<0.01)$. Lipase activity were reduced linearly by $\operatorname{Val}(P<0.05)$. In experiment 2, Leu and Val markedly increased a-amylase activity $(P<$ $0.05)$, decreased lipase activity $(P<0.05)$. The activities of trypsin and chymotrypsin were not affected by the three amino acids $(P>0.05)$, and there was no interaction among them $(P>0.05)$.

Conclusion: This study demonstrated that Leu, lle and Val can stimulate the secretion of pancreatic enzymes in vitro, especially a-amylase. There was no interaction between the three amino acids on the activities of a-amylase, trypsin and chymotrypsin.

\section{Background}

Negative energy balance of dairy cows in the early stage of lactation is a universal issue during feeding, which is very critical for the health status, milk production and reproductive performance of animals. Starch is usually the most substantial energy source in the ration of high-yielding ruminants and the energy utilization efficiency degraded in the rumen is $75 \%$ of that digested in the small intestine [1]. However, the digestibility of starch in small intestine of dairy cows is limited, ranging from 50$60 \%$ [2]. With the increase of rumen starch content in ruminants, starch digestibility could decrease in small intestine, subsequently leading to energy waste and potential hindgut acidosis [3]. Thus, improving the digestibility of starch in small intestine is a breakthrough to solve the negative energy balance and acidosis of lactating cows.

The pancreas is the main sites for the synthesis of digestive enzymes in mammals. The digestion of post-ruminal nutrients in ruminants mainly depends on digestive enzymes secreted by the pancreas, including a-amylase, lipase, trypsin and chymotrypsin. Ninety percentage of them exist in pancreatic proteins and are the major secreted proteins for the body. A number of scholars have shown that insufficient secretion of a-amylase in the pancreas of ruminants is a key factor limiting the utilization of starch in the small intestine $[4,5]$. Therefore, the improvement of exocrine function from pancreatic plays an important role in promoting the digestion of small intestinal nutrients in ruminants.

Branched chain amino acids (BCAAs) have various biological functions of energy supply, regulation of glucose metabolism and synthesis and secretion of hormones [6-8], including Leu, lle and Val. Swanson [9] reports that increasing diet protein percentage increased the secretion of a-amylase in the pancreas of beef steers. It has been suggested that duodenal infusion of Leu increased the secretion of a-amylase in the pancreas of dairy goats and Holstein heifers [10,11]. Zhao's data [12] showed that lle can increase digestive enzyme activities of intestine and hepatopancreas in juvenile Jian crap. It has been proved that appropriate Val levels can increase significantly the activities of amylase, lipase and protease in grass carp [13]. However, there are few studies have been done on the interaction of three BCAAs with pancreatic digestive enzymes activity in ruminants. Therefore, The objective of this study was to investigate three BCAAs and interactive effects on digestive enzymes secretion from pancreas collected of Holstein dairy cows by tissue incubation in vitro.

Page 2/12 


\section{Materials And Methods}

\section{Animals and Experimental Design \\ Experiment 1}

Five Holstein dairy cows were slaughtered. Pancreas tissue was removed immediately, rinsed with ice-cold normal saline $(0.9 \%$ $\mathrm{Nacl}$ ) and transported to the laboratory. Subsequently, the piece was transferred to ice and peeled off, cut into approximately $2 \times$ $2 \mathrm{~mm}$ small segments (approximately $100 \mathrm{mg}$ ) were blotted dry with paper towels, weighed using a glass weigh funnel. Incubation of pancreatic tissue ussing methods described by Swanson et al. [14]. Tissue patches were placed in oxygenated KRB buffer containing no amino acid (control, $0 \mathrm{mg} / \mathrm{mL}$ ), leu, lle or Val $(2.62,5.24$ or $10.48 \mathrm{mg} / \mathrm{mL}$ ). Each treatment was repeated for five times and incubated in a $39^{\circ} \mathrm{C}$ shaking water bath at 90 oscillations/min for $60 \mathrm{~min}, 120 \mathrm{~min}$ or $180 \mathrm{~min}$, respectively. The $\mathrm{pH}$ of all buffers was adjusted to 7.4 so that $\mathrm{pH}$ would not influence enzyme release. Substrates were present the entire incubation period.

\section{Experiment 2}

Five Holstein dairy cows were slaughtered and the pancreas tissues were removed immediately, which treatment method was the same as experiment 1 . Concentration of three amino acids in the control group was $0 \mathrm{mg} / \mathrm{mL}$, and that in the treatment group was $5.24 \mathrm{mg} / \mathrm{mL}$. The incubation time was 60 minutes.

\section{Sample collection and analysis}

At the end of incubation time, amino acid culture plates with different concentration of substrates were taken out and placed on ice. Then $700 \mu \mathrm{L}$ KRB solution was extracted from each hole of the culture plate with a pipette gun and stored in labeled freezing tube at $-20^{\circ} \mathrm{C}$ until analysis for enzyme activities release. A separate aliquot of tissue was homogenized in saline and stored and stored in labeled freezing tube at $-20^{\circ} \mathrm{C}$ until analysis of enzyme activities.

KRB and homogenate samples were used to determine a-amylas activity [15]. The activitis of trypsin and lipase were analysed by using the method of Geiger et al. [16] and Xu et al. [17]. Detection kits (Nanjing Jiancheng Bioengineering Institute, Nanjing, China) was used to analyse chymotrypsin activities within one week. Enzyme activities were expressed in units (one unit is defined as $1 \mu \mathrm{mol}$ product released a-amylase, trypsin and chymotrypsin per minute at $39^{\circ} \mathrm{C}$ ).

\section{Statistical analysis}

The data for the digesta enzyme activities were analyzed using the general linear model procedure of SAS 9.2 (SAS Institute, Cary, NC, USA) to determine the effects of BCAAs (Leu, lle and Val). One-way analysis of variance was done for all groups within an experiment, and the Duncan multiple-range test was used to compare the significance among group means. Differences were considered significant at $P<0.05$ and and as tendencies toward significance at $0.05<P<0.10$.

\section{Results}

The effects of three BCAAs on the activities of trypsin and chymotrypsin in the pancreatic tissue from dairy cows were not significantly different. Val had no significant influence on digestive enzyme activity in pancreatic tissueland incubation in KRB for 120 or $180 \mathrm{~min}$ had the same significant effect on enzyme activity as incubation for $60 \mathrm{~min}$, therefore, not presented in tables.

\section{Experiment 1}

Leu 
A quadratic response $(P<0.01)$ was observed for the $\alpha$-amylase activity increasing in $\mathrm{KRB}$ buffer $(\mathrm{U} / \mathrm{mL})$ and pancreatic tissue (U/g prot) with the increase of Leu concentration and reaching the highest value at 5.24 $\mathrm{mg} / \mathrm{mL}$ for incubation time of $60 \mathrm{~min}$ (Table 1). The results obtained from the preliminary analysis of the trypsin and chymotrypsin activities of KRB are summarised in Table 2 . The figures show that the activity of trypsin $(\mathrm{U} / \mathrm{mL})$ increased linearly $(P<0.05)$. However, activity of the chymotrypsin $(\mathrm{U} / \mathrm{mL})$ was not affected $(P>0.05)$ by Leu compared with the control group $(0 \mathrm{mg} / \mathrm{mL})$. It was concluded that the optimum concentration of Leu to promote pancreatic enzyme secretion was $5.24 \mathrm{mg} / \mathrm{mL}$.

\section{Table 1}

Effects of Leu on $\alpha$-amylase activity at different incubating time in vitro

\begin{tabular}{|c|c|c|c|c|c|c|c|}
\hline \multirow[t]{2}{*}{ Incubating time(min) } & \multicolumn{4}{|c|}{ Levels of Leu (mg/mL) } & \multirow[t]{2}{*}{$\mathrm{SEM}^{1}$} & \multicolumn{2}{|c|}{$P$ value $^{2}$} \\
\hline & 0 & 2.62 & 5.24 & 10.48 & & Linear & Quadratic \\
\hline \multicolumn{8}{|l|}{$\mathrm{KRB}$} \\
\hline 60 & 1644.7 & 2312.8 & 2823.4 & 2112.7 & 81.12 & 0.286 & $<0.01$ \\
\hline 120 & 1178.6 & 2140.6 & 2432.8 & 2182.4 & 94.20 & 0.402 & $<0.01$ \\
\hline 180 & 1415.5 & 1088.9 & 1203.4 & 1088.5 & 76.04 & 0.253 & 0.548 \\
\hline \multicolumn{8}{|l|}{ Tissue } \\
\hline 60 & $2641.0^{\mathrm{b}}$ & $2542.7^{\mathrm{b}}$ & $3758.1^{\mathrm{a}}$ & $2869.1^{b}$ & 92.33 & 0.647 & $<0.01$ \\
\hline 120 & 2782.8 & 2993.4 & 3113.9 & 2356.3 & 222.21 & 0.281 & 0.962 \\
\hline 180 & 1726.4 & 1838.9 & 2282.2 & 1763.3 & 185.83 & 0.429 & 0.733 \\
\hline \multicolumn{8}{|l|}{ Total } \\
\hline 60 & $4418.5^{\mathrm{c}}$ & $5002.0^{\mathrm{b}}$ & $6486.0^{\mathrm{a}}$ & $5119.8^{\mathrm{b}}$ & 68.42 & 0.515 & $<0.01$ \\
\hline 120 & 3812.6 & 4918.5 & 5530.1 & 4519.0 & 333.48 & 0.823 & 0.384 \\
\hline 180 & 3075.8 & 2920.6 & 3685.0 & 2893.2 & 135.15 & 0.521 & 0.602 \\
\hline
\end{tabular}

${ }^{1}$ Pooled standard error of mean, $\mathrm{n}=5$.

${ }^{2}$ Linear relationship between Leu level and $\alpha$-amylase activity.

a,b,c Means in a row with different superscript letters differ $(p<0.05)$.

\section{Table 2}

Effects of Leu on trypsin and chymotrypsin activities at different incubating time in vitro 


\begin{tabular}{|c|c|c|c|c|c|c|c|c|}
\hline \multirow[t]{2}{*}{ Items } & \multirow{2}{*}{$\begin{array}{l}\text { Incubating } \\
\text { time (min) }\end{array}$} & \multicolumn{4}{|c|}{ Levels of Leu (mg/mL) } & \multirow[t]{2}{*}{$\mathrm{SEM}^{1}$} & \multicolumn{2}{|c|}{$P$ value $^{2}$} \\
\hline & & 0 & 2.62 & 5.24 & 10.48 & & Linear & Quadratic \\
\hline \multirow[t]{3}{*}{ Trypsin } & 60 & $1365^{\mathrm{b}}$ & $1421^{b}$ & $1562^{\mathrm{a}}$ & $1583^{\mathrm{a}}$ & 75.24 & 0.032 & 0.710 \\
\hline & 120 & $1624^{\mathrm{b}}$ & $2035^{a b}$ & $2206^{\mathrm{ab}}$ & $2683^{a}$ & 54.69 & 0.016 & 0.262 \\
\hline & 180 & $2454^{\mathrm{b}}$ & $2578^{b}$ & $3037^{a}$ & $3258^{a}$ & 57.35 & 0.035 & 0.429 \\
\hline \multirow[t]{3}{*}{ Chymotrypsin } & 60 & 2045.8 & 3673.2 & 2955.5 & 3336.2 & 168.58 & 0.425 & 0.501 \\
\hline & 120 & 1938.2 & 2534.7 & 2183.4 & 2596.4 & 231.56 & 0.398 & 0.724 \\
\hline & 180 & 2680.5 & 3053.5 & 2812.3 & 3274.6 & 185.37 & 0.546 & 0.632 \\
\hline
\end{tabular}

${ }^{1}$ Pooled standard error of mean, $\mathrm{n}=5$.

${ }^{2}$ Linear relationship between Leu level and trypsin and chymotrypsin activities.

a,b Means in a row with different superscript letters differ $(p<0.05)$.

Ile

As shown in Table 3, The $\alpha$-amylase activity in $\mathrm{KRB}$ buffer (U/mL) and total $\alpha$-amylase (U/g tissue) increased $(P<0.01)$ linearly with the increase of Ile levels, but there was no significant difference $(P>0.05)$ at the concentration of $5.24 \mathrm{mg} / \mathrm{mL}$ and $10.48 \mathrm{mg} / \mathrm{mL}$. $\alpha$-amylase activity (U/g prot) in pancreatic tissue was not affected $(P>0.05)$ by Ile concentration. Table 4 presents the results obtained from the preliminary analysis of trypsin and chymotrypsin activities in KRB solution. It can be seen that the activity of trypsin (U/mL) increased linearly with the increase of Ile concentration $(P<0.05)$ when the incubation time was 120 or 180 min. However, there was no significant difference $(P>0.05)$ at the concentration of $5.24 \mathrm{mg} / \mathrm{mL}$ and $10.48 \mathrm{mg} / \mathrm{mL}$. The chymotrypsin activity $(\mathrm{U} / \mathrm{mL})$ was not affected by the levels of Ile at 60 or $120 \mathrm{~min}(P>0.05)$, but decreased linearly with the increase of the levels of Ile at $180 \mathrm{~min}(P<0.01)$. Based on the above results, we selected $5.24 \mathrm{mg} / \mathrm{mL}$ as the incubation concentration of Ile in subsequent experiments.

\section{Table 3}

Effects of Ile on $\alpha$-amylase activity in KRB solution and pancreatic tissues at different incubating time in vitro 


\begin{tabular}{|c|c|c|c|c|c|c|c|}
\hline \multirow[t]{2}{*}{ Incubating time (min) } & \multicolumn{4}{|c|}{ Levels of Ile $(\mathrm{mg} / \mathrm{mL})$} & \multirow[t]{2}{*}{$\mathrm{SEM}^{1}$} & \multicolumn{2}{|c|}{$P$ value $^{2}$} \\
\hline & 0 & 2.62 & 5.24 & 10.48 & & Linear & Quadratic \\
\hline \multicolumn{8}{|l|}{ KRB } \\
\hline 60 & $364.1^{\mathrm{b}}$ & $464.9^{\mathrm{b}}$ & $8588.3^{\mathrm{a}}$ & $7374.1^{\mathrm{a}}$ & 253.03 & $<0.01$ & 0.256 \\
\hline 120 & $990.4^{\mathrm{b}}$ & $822.8^{\mathrm{b}}$ & $5666.6^{\mathrm{a}}$ & $7398.0^{\mathrm{a}}$ & 335.23 & $<0.01$ & 0.081 \\
\hline 180 & $1212.3^{\mathrm{b}}$ & $1467.5^{\mathrm{b}}$ & $10106.4^{\mathrm{a}}$ & $8412.0^{\mathrm{a}}$ & 244.79 & $<0.01$ & 0.327 \\
\hline \multicolumn{8}{|l|}{ Tissues } \\
\hline 60 & 2589.0 & 2622.0 & 3590.3 & 2902.9 & 209.35 & 0.436 & 0.458 \\
\hline 120 & 2120.2 & 2459.2 & 2497.5 & 3526.9 & 247.80 & 0.502 & 0.280 \\
\hline 180 & 1897.3 & 1854.8 & 2059.6 & 2224.9 & 96.16 & 0.769 & 0.316 \\
\hline \multicolumn{8}{|l|}{ Total } \\
\hline 60 & $2953.1^{b}$ & $3077.2^{\mathrm{b}}$ & $12273.9^{a}$ & $10529.5^{a}$ & 529.29 & $<0.01$ & 0.482 \\
\hline 120 & $3165.1^{b}$ & $3251.3^{\mathrm{b}}$ & $7827.9^{a}$ & $11991.9^{a}$ & 487.06 & $<0.01$ & 0.065 \\
\hline 180 & $3119.0^{\mathrm{b}}$ & $3353.7^{b}$ & $11711.0^{\mathrm{a}}$ & $9828.6^{\mathrm{a}}$ & 114.66 & $<0.01$ & 0.513 \\
\hline
\end{tabular}

${ }^{1}$ Pooled standard error of mean, $\mathrm{n}=5$.

${ }^{2}$ Linear relationship between Ile level and $\alpha$-amylase activity.

a,b Means in a row with different superscript letters differ $(p<0.05)$.

\section{Table 4}

Effects of Ile on trypsin and chymotrypsin activities at different incubating time in vitro

\begin{tabular}{|c|c|c|c|c|c|c|c|c|}
\hline \multirow[t]{2}{*}{ Items } & \multirow{2}{*}{$\begin{array}{l}\text { Incubating } \\
\text { time (min) }\end{array}$} & \multicolumn{4}{|c|}{ Levels of Leu $(\mathrm{mg} / \mathrm{mL})$} & \multirow[t]{2}{*}{$\mathrm{SEM}^{1}$} & \multicolumn{2}{|c|}{$P$ value ${ }^{2}$} \\
\hline & & 0 & 2.62 & 5.24 & 10.48 & & Linear & Quadratic \\
\hline \multirow[t]{3}{*}{ Trypsin } & 60 & 1378 & 1321 & 1285 & 1407 & 34.12 & 0.962 & 0.161 \\
\hline & 120 & $1475^{\mathrm{b}}$ & $1725^{\mathrm{a}}$ & $1853^{\mathrm{a}}$ & $1883^{\mathrm{a}}$ & 45.83 & 0.035 & 0.540 \\
\hline & 180 & $2064^{\mathrm{b}}$ & $2319^{b}$ & $2960^{\mathrm{a}}$ & $3238^{a}$ & 49.62 & 0.047 & 0.823 \\
\hline \multirow[t]{3}{*}{ Chymotrypsin } & 60 & 2497.1 & 4112.1 & 5919.9 & 4634.4 & 324.62 & 0.672 & 0.095 \\
\hline & 120 & 1508.0 & 2732.7 & 2481.3 & 3598.0 & 309.80 & 0.259 & 0.413 \\
\hline & 180 & $6010.5^{\mathrm{a}}$ & $2563.7^{\mathrm{b}}$ & $1731.1^{\mathrm{bc}}$ & $1433.2^{\mathrm{C}}$ & 143.17 & $<0.01$ & 0.586 \\
\hline
\end{tabular}


${ }^{1}$ Pooled standard error of mean, $\mathrm{n}=5$.

${ }^{2}$ Linear relationship between Ile level and trypsin and chymotrypsin activities.

a,b,c Means in a row with different superscript letters differ $(p<0.05)$.

Val

The $\alpha$-amylase activity $(\mathrm{U} / \mathrm{mL})$ in $\mathrm{KRB}$ solution changed quadratically with the increase of Val concentration $(P=0.055)$, reaching the peak value at $5.24 \mathrm{mg} / \mathrm{mL}$. The activity of lipase $(\mathrm{U} / \mathrm{mL})$ decreased linearly $(P<0.05)$. However, Val had no influence on trypsin $(\mathrm{U} / \mathrm{mL})$ and chymotrypsin $(\mathrm{U} / \mathrm{mL})$ activities $(P>$ 0.05) (Table 5).

\section{Table 5}

Effects of Val on enzyme activity at different incubating time in vitro

\begin{tabular}{ccccccccc}
\hline \multirow{2}{*}{ Items } & \multicolumn{3}{c}{ Levels of Val $(\mathrm{mg} / \mathrm{mL})$} & SEM $^{1}$ & \multicolumn{2}{c}{$P$ value $^{2}$} \\
\cline { 2 - 4 } & 0 & 2.62 & 5.24 & 10.48 & & & Linear & Quadratic \\
\hline a-amylase & $756^{\mathrm{b}}$ & $1007^{\mathrm{ab}}$ & $1527^{\mathrm{a}}$ & $1122^{\mathrm{ab}}$ & 120.2 & 0.082 & 0.055 \\
Lipase & $342^{\mathrm{a}}$ & $260^{\mathrm{ab}}$ & $281^{\mathrm{ab}}$ & $172^{\mathrm{b}}$ & 27.3 & 0.042 & 0.129 \\
Trypsin & 48.6 & 37.8 & 38.4 & 47.4 & 6.0 & 0.957 & 0.730 \\
Chymotrypsin & 3.29 & 3.69 & 2.90 & 4.23 & 0.392 & 0.578 & 0.729 \\
\hline
\end{tabular}

${ }^{1}$ Pooled standard error of mean, $\mathrm{n}=5$.

${ }^{2}$ Linear relationship between Val level and enzyme activity.

a,b,c Means in a row with different superscript letters differ $(p<0.05)$.

Experiment 1 showed that the optimum concentration and incubation time of promoting pancreatic enzyme secretion in dairy cows were $5.24 \mathrm{mg} / \mathrm{mL}$ and $60 \mathrm{~min}$, respectively, so it was used as the incubation condition of experiment 2 .

Experiment 2 
The interaction influence of three amino acids on pancreatic digestive enzymes (U/mL) was shown in Table

6. Leu and Val markedly increased $\alpha$-amylase activity $(P<0.05)$, Ile had no effect on $\alpha$-amylase $(P>0.05)$, and there was no interaction among the three amino acids $(P>0.05)$. Leu and Val decreased significantly lipase activity in KRB buffer $(P<0.05)$, but Ile had no effect $(P>0.05)$. There was significant interaction among the three amino acids $(P<0.05)$. It is apparent from this table that the activities of trypsin and chymotrypsin were not affected by the three amino acids $(P>0.05)$, and there was no interaction among them $(P>0.05)$.

\section{Table 6}

Interaction of BCAAs on pancreatic enzyme activities from dairy cows in vitro

\begin{tabular}{|c|c|c|c|c|c|c|c|c|c|c|c|c|c|}
\hline \multirow{3}{*}{$\begin{array}{l}\text { Leu }(\mathrm{mg} / \mathrm{mL}) \\
\text { Ile }(\mathrm{mg} / \mathrm{mL}) \\
\text { Val }(\mathrm{mg} / \mathrm{mL})\end{array}$} & \multicolumn{4}{|c|}{0} & \multicolumn{4}{|c|}{5.24} & \multirow[t]{3}{*}{ SEM } & \multirow{2}{*}{\multicolumn{4}{|c|}{$P$ value }} \\
\hline & \multicolumn{2}{|c|}{0} & \multicolumn{2}{|c|}{5.24} & \multicolumn{2}{|c|}{0} & \multicolumn{2}{|c|}{5.24} & & & & & \\
\hline & 0 & 5.24 & 0 & 5.24 & 0 & 5.24 & 0 & 5.24 & & Leu & Ile & Val & Interaction \\
\hline$\alpha$-amylase & 756 & 1327 & 1056 & 1381 & 1265 & 1618 & 1345 & 1734 & 80.0 & 0.018 & 0.350 & 0.008 & 0.971 \\
\hline Lipase & $342^{b}$ & $281^{b}$ & $651^{\mathrm{a}}$ & $224^{\mathrm{b}}$ & $319^{b}$ & $247^{\mathrm{b}}$ & $177^{\mathrm{b}}$ & $199^{\mathrm{b}}$ & 30.7 & 0.005 & 0.740 & 0.006 & $<0.01$ \\
\hline Trypsin & 49 & 38 & 22 & 37 & 34 & 53 & 46 & 36 & 3.9 & 0.479 & 0.322 & 0.654 & 0.483 \\
\hline Chymotrypsin & 3.3 & 2.9 & 4.0 & 4.6 & 3.5 & 8.2 & 7.8 & 4.7 & 0.7 & 0.088 & 0.554 & 0.762 & 0.379 \\
\hline
\end{tabular}

${ }^{1}$ Pooled standard error of mean, $\mathrm{n}=5$.

${ }^{2}$ Linear relationship between BCAAs level and enzyme activity.

a,b Means in a row with different superscript letters differ $(p<0.05)$.

\section{Discussion}

With the increasing of milk production, a huge challege facing researchers and breeders is how to meet the nutritional needs of dairy cows more effectively [18]. In order to solve this problem, high-concentrate diets with cereal starch as the major energy feed are increased continuously in production to satisfy the energy needs of ruminants, resulting in a large number of starch entering the small intestine. However, the ability of small intestine to digest starch is limited. Inadequate activity of digestive enzymes secreted by pancreas may be one of the reasons for this limitation. Based on this, we need to determine whether nutrients affect the production and secretion of pancreatic enzymes. Interaction experiments conducted in vivo complicate the interpretation of data. As a result, understanding of the direct interaction of pancreatic exocrine enzymes can be aided by means of using tissue incubation method in vitro[14] .

Leu is not only one of the essential amino acids (EAAs) in mammals but also the substrate for protein synthesis, which plays an important regulatory role in protein synthesis and metabolic turnover in tissues as an effective nutrient factor $[19,20]$. When either administrated orally or injected with Leu, protein synthesis in other tissues such as pancreas, heart, liver and skeletal muscle is increased [7, 21, 22]. It was identified that Leu stimulates milk protein synthesis in dairy cows through the mTOR signaling pathway $[23,24,25]$. Swanson et al. [26] observed that casein infusion in abomasum stimulated the activity of pancreatic a-amylase, but did not affect the trypsin and chymotrypsin activity. Yu et al. and Liu et al. [10, 11, 27]identified that 
the a-amylase activity was increased by the duodenal infusion of Leu or phenylalanine (Phe). In contrast, a research has shown that BCAAs (especially Leu) could reduce the activity of a-amylase in rat pancreas for a long time [28]. In this experiment, adding Leu to KRB improved pancreatic a-amylase activity by quadratic curve and linearly increased the trypsinase activity, but had no influence on the chymotrypsin activity. The differences may be attributed to different experimental animals and regulation way.

Pancreatic exocrine function plays an critical role in digestion and absorption of small intestinal nutrients. The regulatory mechanism of amino acids on pancreatic digestive enzymes secretion remains not well understood in ruminants. Previous published studies suggested that casein regulates pancreatic a-amylase secretion at the transcriptional level, and which had interspecific differences in its regulation $[9,29]$. Moreover, BCAAs (especially Leu) could affect pancreatic enzyme activity at translational level through mTOR signaling pathway [30], and also alter expression of gene mRNA to regulate its activity at transcriptional level. Generally, in nonruminants, Leu decreased the mRNA expression of a-amylase and inhibits the secretion of a-amylase $[28,29]$. It was hypothesized that there were interspecific differences in the regulation of pancreatic a-amylase secretion by Leu. Therefore, The expression of a-amylase may be increased by Leu and promoted a-amylase activity in ruminants, which was consistent with increasing of a-amylase activity in dairy cows when Leu level was increased in the present experiment.

Ile and Val are similar to Leu and also substrates for protein synthesis. It has been vertified that increasing the level of lle in the diet could increase the dry matter, milk protein and milk fat content of lactating sows [31] and increase digestive enzyme activities of intestine and hepatopancreas in juvenile Jian crap [12]. Liu et al. [32]reported that the activity of pancreatic aamylase and trypsin in dairy heifers were increased linearly with the lle infusion doses. A recent study has shown that the total concentrations of digestive enzymes in pancreatic tissue of dairy goats were significantly increased by high levels of lle, especially a-amylase, but had no effect on lipase [33]. We found different results from previous study by using in vitro system. In this experiment, the chymotrypsin activity in culture medium decreased linearly with the increase of isoleucine level when the incubation time was $180 \mathrm{~min}$. This may be attributed to different animal models. In addition, Results of our experiment also demonstrated that a-amylase activity in the buffer changed quadratically with the concentration of Val, which reached the highest value when the concentration of Val was $5.24 \mathrm{mg} / \mathrm{mL}$.

BCAAs (Leu, lle, Val) are EAA which cannot be synthesized in animals and playing an important role in the growth and development of animals. They account for $35 \%$ 40\% of the total essential amino acids and $14 \% \sim 18 \%$ of the total amino acids [34]. At present, comparatively little is known about the interaction of three BCAAs on the secretion of pancreatic digestive enzymes in ruminants. It was reported that casein increased the pancreatic a-amylase and trypsin activity in Holstein steer calves by enhancing the size of pancreas [35]. Our results showed that Leu and Val significantly increase the activity of secreting a-amylase from pancreas and decrease the activity of lipase. It was also found that there was a significant interaction between the three amino acids on lipase activity. However, this three amino acids did not interact with a-amylase, trypsin and chymotrypsin and not affect digestive enzyme activities. The difference between this observation and previous results may be due to the difference in amino acid composition, resulting in different regulation way and effects on pancreas [36].

\section{Conclusions}

The present study confirmed that Leu, lle and Val can stimulate the secretion of pancreatic enzymes in vitro, especially aamylase. There was no interaction between the three BCAAs on the activities of a-amylase, trypsin and chymotrypsin. A better understanding of the specific mechanism of Leu, lle and Val regulating digestive enzyme secretion should be significant to improve the digestibility of starch in small intestine of ruminants.

\section{Abbreviations}

Leu:Leucine; Ile:Isoleucine; Val:Valine; KRB:Krebs ringer bicarbonate; BCAAs:Branched chain amino acids; EAAs:Essential amino acids; Phe:Phenylalanine.

\section{Declarations}

Page $9 / 12$ 


\section{Ethics declarations}

\section{Ethics approval and consent to participate}

The study was approved by the Institutional Review Committee of Inner Mongolia Agricultural University. All participants obtained written informed consent.

\section{Consent for publication}

Not applicable.

\section{Competing interests}

The authors declare that they have no competing interests.

\section{Availability of supporting data}

The data used and/or analysed during the current study are available from the first author on reasonable request.

\section{Authors' information}

Affiliations

College of Animal Science, Inner Mongolia Agricultural University, Hohhot, Inner Mongolia, China, 010018

Meng Ya Wang. Xuan Ma. Dong Lin Wu. Kai Shao. Ru Li \& Ming Xu.

College of Animal Science and Technology, Northwest A\&F University, Yangling, Shanxi, China, 712100

Meng Ya Wang \& Xue Liang Zhao.

\section{Author' contributions}

MYW and MX conceived and designed the study; XM and DLW analyzed and interpreted the data; XLZ helped draft the manuscript; KS and RL revised the language of the entire manuscript; MYW and MX wrote the manuscript; All authors have read and approved the final manuscript.

\section{Corresponding authors}

Correspondence to Ming Xu.

\section{Acknowledgements}

The authors are grateful to all members in our group for their technical assistances and help in animal preparation and sample analysis.

\section{Funding}

This research was supported by grant Inner Mongolia Autonomous Region Colleges and Universities "Young Science and Technology Talents Support Program"

\section{References}

1. Harmon DL. Understanding starch utilization in the small intestine of cattle. Asian-Aust J Anim Sci 2009; 22: 915-22.

2. Xu M, Yao JH, Harmon DL, Han J C. Mathematical models to predict site and extent of starch digestion in the gastrointestinal tract of cattle. Chinese Agriculture Bulletin 2007; 23: 64-73. 
3. Gressley TF, Hall MB, Armentano LE. Ruminant nutrion symposium: productivity, digestion, and health responses to hindgut acidosis in ruminants. J Anim Sci 2011; 89: 1120-30.

4. Harmon DL, Yamka RM, Elam NA. Factors affecting intestinal starch digestion in ruminants: a review. Can J Anim Sci 2004; 84: 309-18.

5. Huntington GB, Harmon DL, Richards CJ. Sites, rates and limits of starch digestion and glucose metabolism in growing cattle. J Anim Sci 2006; 84: E14-24.

6. Rulquin H, Pisulewski PM. Effects of graded levels of duodenal infusions of leucine on mammary uptake and output in lactating dairy cows. J Dairy Res 2006;73: 328-39.

7. Yin YL, Yao K, Liu ZJ, Gong M, Ruan Z, Deng D, et al. Supplementing l-leucine to a low-protein diet increases tissue protein synthesis in weanling pigs. Amino Acids 2010; 39:1477-86.

8. Du Y, Meng QS, Zhang Q. Isoleucine or valine deprivation stimulates fat loss via increasing energy expenditure and regulating lipid metabolism in WAT. Animo Acids 2012; 43: 725-34.

9. Swanson KC, Kelly N, Salim H, Wang YJ, Holligan S, Fan MZ, et al. Pancreatic mass, cellularity, and a-amylase and trypsin activity in feedlot steers fed diets differing in crude protein concentration. J Anim Sci 2008; 86: 909-15.

10. Yu ZP, Xu M, Wang F, Liu K, Yao JH, Wu Z, et al. Effect of duodenal infusion of leucine and phenylalanine on intestinal enzyme activities and starch digestibility in goats. J Liv Sci 2014; 162: 134-40.

11. Liu K, Liu Y, Liu SM, Xu M, Yu ZP, Wang X, et al. Relationships between leucine and the pancreatic exocrine function for improving starch digestibility in ruminants. J Dairy Sci 2015; 98: 2575-82.

12. Zhao J, Liu Y, Jiang J, Wu P, Chen G, Jiang W, et al. Effects of dietary isoleucine on growth, the digestion and absorption capacity and gene expression in hepato-pancreas and intestine of juvenile Jian carp. Aquaculture. 2012; 368-369: 127-8.

13. Luo L, Wang Y G, Li Q, Wang FB, Chen S, Liu B, et al. Research on dietary valine requirement of juvenile grass carp (Ctenopharingodon idella). Chinese Journal of Animal Nutrition 2010; 22: 616-24.

14. Swanson KC, Matthews JC, Woods CA, Harmon DL. Influence of substrate and/or neurohormonal mimic on in vitro pancreatic enzyme release from calves postruminally infused with partially hydrolyzed starch and/or casein. 2003; 81: 1323-31.

15. Walker JA, Harmon DL. Technical note: a simple, rapid assay for a-amylase in bovine pancreatic juice. J Anim Sci 1996; 74 : 658-62.

16. Geiger R, Fritz H. Trypsin, Methods of enzymatic analysis New York (NY): Academic Press 1986; 119-28.

17. Xu M, Du S, Wang J, Yu ZP, Harmon DL, Yao JH. Influence of rumen escape starch on pancreatic exocrine secretion of goats. J Anim Physiol Anim Nutr 2009; 93: 122-9.

18. Sundrum A. Metabolic disorders in the transition period indicate that the dairy cows' ability to adapt is overstressed. Animals 2015; 5: 978-1020.

19. Rajendram R, Preedy V R, Patel V B. Leucine区Protein Functional adaptation in the clinical setting. Branched Chain Amino Acids in Clinical Nutrition. New York: Springer, 2015; 217-227区

20. Suryawan A, Orellana RA, Fiorotto ML, Davis T A. Triennial Growth Symposium: Leucine acts as a nutrient signal to stimulate protein synthesis in neonatal pigs. J Anim Sci 2011; 89: 2004-16.

21. Escobar J, Frank JW, Suryawan A, Nguyen HV, Kimball SR, Jefferson LS, et al. Physiological rise in plasma leucine stimulates muscle protein synthesis in neonatal pigs by enhancing translation initiation factor activation. 2005; 288: 91421.

22. Wilson FA., Suryawan A, Orellana RA, Gazzaneo MC, Nguyen HV, Davis TA. Differential effects of long-term leucine infusion on tissue protein synthesis in neonatal pigs. Amino Acids 2011; 40: 157-65.

23. Toerien CA, Trout DR, Cant JP. Nutritional stimulation of milk protein yield of cows is associated with changes in phosphorylation of mammary eukaryotic initiation factor 2 and ribosomal S6 Kinase 1. J Nutr, 2010; 140: $285-92$.

24. Burgos SA, Dai M, Cant JP. Nutrient availability and lactogenic hormones regulate mammary protein synthesis through the mammalian target of rapamycin signaling pathway. J Dairy Sci 2010; 93: 153-61. 
25. Appuhamy JA, Knoebel NA, Nayananjalie WA, Escobar J, Hanigan MD. Isoleucine and leucine independently regulate mTOR signaling and protein synthesis in MAC-T cells and bovine mammary tissue slices. J Nutr 2012; 142: 484-91.

26. Swanson KC, Benson JA, Matthews JC, Harmon DL. Pancreatic exocrine secretion and plasma concentration of some gastrointestinal hormones in response to abomasal infusion of starch hydrolyzate and/or casein. J Anim Sci 2004; 82: 1781-7..

27. Yu ZP, Xu M, Liu K, Yao JH, Yu HX, Wang F. Leucine markedly regulates pancreatic exocrine secretion in goats. J Anim Physio Anim Nutr 2013; 98: 169-77.

28. Hashimoto N, Hara H. Dietary branched-chain amino acids suppress the expression of pancreatic amylase mRNA in rats. Biosci Biotechnol Biochem 2004; 68:1067-72.

29. Hashimoto N, Hara H. Dietary amino acids promote pancreatic protease synthesis at the translation stage in rats 1 . J Nutr, $2003 ; 133: 3052-7$.

30. Sans MD, Tashiro M, Vogel NL, Kimball SR, D'Alecy LG, Williams JA. Leucine activates pancreatic translational machinery in rats and mice through mTOR independently of CCK and insulin. J Nutr 2006; 136: 1792-99.

31. Richert BT, Goodband RD, Tokach MD, Nelssen JL. Increasing valine, isoleucine, and total branched-chain amino acids for lactating sows. J Anim Sci. 1997; 75: 2117-28.

32. Liu K, Shen J, Cao Y, Cai CJ, Yao JH. Duodenal infusions of isoleucine influence pancreatic exocrine function in dairy heifers. Arch Anim Nutr $2017 ; 72:$ 31-41.

33. Cao YC, Liu K, Liu SM, Guo L,Cai CJ, Yao JH. Isoleucine regulates the synthesis of pancreatic enzymes via the activation of mRNA expression and phosphorylation in the mammalian target of rapamycin signalling pathways in pancreatic tissues . Biomed Res Int, 2019, 2019: 1-7.

34. Shimomura Y, Yamamoto Y, Bajotto G, Sato J, Murakami T, Shimomura N, et al. Nutraceutical effects of branched chain amino acids on skeletal muscle. J Nutr 2006; 136: 529-32.

35. Swanson KC, Matthews JC, Woods CA, Harmon DL. Postruminal administration of partially hpydrolyzed starch and casein influences pancreatic a-amylase expression in calves[J]. J Nutr, 2002; 132: 376-81.

36. Brake DW, Titgemeyer EC, Anderson DE. Duodenal supply of glutamate and casein both improve intestinal starch digestion in cattle but by apparently different mechanisms. J Anim Sci, 2014; 92:4057-67. 